\title{
Streptomyces nanhaiensis sp. nov., a marine streptomycete isolated from a deep-sea sediment
}

\author{
Correspondence \\ Wen-Jun Li \\ wjli@ynu.edu.cn \\ Si Zhang \\ zhsimd@scsio.ac.cn
}

\author{
Xin-Peng Tian, ${ }^{1,2}$ Li-Juan Long, ${ }^{1}$ Fa-Zuo Wang, ${ }^{1}$ Ying $\mathrm{Xu}^{2}{ }^{2}$ Jie Li, ${ }^{1,2}$ \\ Jing Zhang, ${ }^{2}$ Chang-Sheng Zhang, ${ }^{1}$ Si Zhang ${ }^{1}$ and Wen-Jun $\mathrm{Li}^{2}$
}

\author{
${ }^{1}$ Key Laboratory of Marine Bio-Resources Sustainable Utilization, CAS, RNAM Center for Marine \\ Microbiology, CAS, Guangdong Key Laboratory of Marine Materia Medica, South China Sea \\ Institute of Oceanology, Chinese Academy of Sciences, Guangzhou 510301, PR China \\ ${ }^{2}$ Key Laboratory of Microbial Diversity in Southwest China, Ministry of Education and Laboratory for \\ Conservation and Utilization of Bio-Resources, Yunnan Institute of Microbiology, \\ Yunnan University, Kunming 650091, PR China
}

\begin{abstract}
A novel aerobic streptomycete, strain SCSIO $01248^{\top}$, was isolated from a sample of deep-sea sediment collected from the northern South China Sea, at a depth of $1632 \mathrm{~m}$. This isolate formed yellow-white substrate mycelium and grey-white aerial hyphae. Phylogenetic analysis based on $16 S$ rRNA gene sequences indicated that strain SCSIO $01248^{\top}$ was most closely related to Streptomyces radiopugnans $\mathrm{R}^{\top} 7^{\top}$ ( $98.8 \%$ sequence similarity), S. macrosporus NBRC $14748^{\top}$ $(97.5 \%)$ and S. megasporus NBRC $14749^{\top}$ (97.3\%). The novel strain could, however, be readily differentiated from S. radiopugnans DSM $41901^{\top}$ on the basis of some physiological and cellular chemical characteristics; the level of DNA-DNA relatedness between these two strains was only $40 \%$. Based on phylogenetic and phenotypic evidence, strain SCSIO $01248^{\top}$ represents a novel species, for which the name Streptomyces nanhaiensis sp. nov. is proposed. The type strain is SCSIO $01248^{\top}\left(=\mathrm{DSM} 41926^{\top}=\right.$ KCTC $19401^{\top}=$ CCTCC AA $\left.208007^{\top}\right)$.
\end{abstract}

Streptomyces is the largest genus of the phylum Actinobacteria and is the type genus of the family Streptomycetaceae (Kämpfer, 2006). The members of the genus Streptomyces are Gram-positive bacteria with high $\mathrm{G}+\mathrm{C}$ contents and are characterized by a complex secondary metabolism. They produce over two-thirds of the clinically useful antibiotics of natural origin (Kieser et al., 2000). Streptomycetes are found predominantly in soil and in decaying vegetation, and most produce spores. A gram of soil, an important habitat for this group of bacteria, typically contains $10^{4}-10^{7}$ c.f.u. of streptomycetes, representing 1$20 \%$, or an even larger proportion, of the total counts of viable bacteria (Schrempf, 2006). In contrast, the total numbers of culturable actinobacteria in fresh samples of marine sediments are very low (usually about $10^{2}-10^{3}$ c.f.u. $\mathrm{g}^{-1}$ ), especially in samples collected more than $1000 \mathrm{~m}$ below the sea surface. In the South China Sea, for example, Streptomyces species are scarce in sediment samples collected at depths beyond $1000 \mathrm{~m}$, even though Streptomyces and Micromonospora species predominate in sediments collected at depths of 30-300 $\mathrm{m}$ (unpublished results).

Abbreviations: DPG, diphosphatidylglycerol; PE, phosphatidylethanolamine; PG, phosphatidylglycerol; PI, phosphatidylinositol; PIM, phosphatidylinositol mannosides; PL, phospholipid.

The GenBank/EMBL/DDBJ accession number for the 16S rRNA gene sequence of strain SCSIO $01248^{\top}$ is GQ871748.
During our investigation of marine actinobacterial resources in the South China Sea, a novel isolate, strain SCSIO $01248^{\mathrm{T}}$, was obtained from a sediment sample collected at a depth of $1632 \mathrm{~m}$, a pH of about 7.8 and a temperature of $5{ }^{\circ} \mathrm{C}$. Here we report the classification and identification of this new isolate based on a polyphasic taxonomic approach. Strain SCSIO $01248^{\mathrm{T}}$ was isolated from a sediment sample collected below the northern South China Sea, at $118^{\circ} 57.006^{\prime} \mathrm{N} 22^{\circ} 0.574^{\prime} \mathrm{E}$, using methods described by Tian et al. (2009). A grey-white colony was picked after incubation at $28{ }^{\circ} \mathrm{C}$ for 3 weeks on humic acid-vitamin agar (Hayakawa \& Nomura, 1987) that had been made with $70 \%(\mathrm{v} / \mathrm{v})$ natural seawater in distilled water (instead of pure distilled water). The purified strain was maintained both on ISP medium 2 and as $20 \%(\mathrm{w} / \mathrm{v})$ glycerol suspensions at $-80{ }^{\circ} \mathrm{C}$. Biomass for chemotaxonomic and molecular systematic studies was obtained by cultivation in ISP 2 broth or, for the fatty acid analysis, trypticase soy broth (Difco) at $28{ }^{\circ} \mathrm{C}$ for 1 week, with continuous shaking at 150 r.p.m.

For morphological and cultural characterization, strain SCSIO $01248^{\mathrm{T}}$ was incubated at $28{ }^{\circ} \mathrm{C}$ for 28 days on ISP media 2, 3, 4 and 5 and Czapek's solution agar (Waksman, 1961), nutrient agar (Difco) and potato agar (Waksman, 1961). Cell morphology was examined using a light microscope (BH2; Olympus), a transmission electron microscope 
(JEM-1010; JEOL) and a scanning electron microscope (JSM $5600 \mathrm{LV}$; JEOL) and cells that had been incubated for 14 or 28 days on ISP medium 2 modified by replacement of the pure distilled water with $50 \%(\mathrm{v} / \mathrm{v})$ seawater in distilled water. Diffusible pigments were investigated by comparing cultures against the most suitable colour chips from the ISCC-NBS Color Charts (Kelly, 1964).

The Gram-reaction test was performed as described by Smibert \& Krieg (1994). Tests for hydrolysis of starch, gelatin, cellulose and Tweens 20, 40,60 and 80, milk coagulation and peptonization and utilization of urea were carried out as described by Tindall et al. (2007). The methods used for determination of $\mathrm{H}_{2} \mathrm{~S}$ and melanin production, nitrate reduction, production of soluble pigments and use of various substrates (each at a final concentration of $1 \%, \mathrm{w} / \mathrm{v}$ ) as sole carbon sources were those described by Williams et al. (1989). Catalase activity was evaluated by the production of oxygen bubbles in $3 \%(\mathrm{v} / \mathrm{v})$ $\mathrm{H}_{2} \mathrm{O}_{2}$ and oxidase activity by the use of oxidase reagent (bioMérieux). Ranges of temperature and $\mathrm{pH}$ for growth and tolerance of $\mathrm{NaCl}$ were evaluated as described by $\mathrm{Xu}$ et al. (2005) using ISP medium 2 as the basal medium, made with $50 \%(\mathrm{v} / \mathrm{v})$ natural seawater in distilled water (instead of pure distilled water). The medium $\mathrm{pH}$ was adjusted using acetate/citrate buffer ( $\mathrm{pH} 4-6$ ), $\mathrm{KH}_{2} \mathrm{PO}_{4} / \mathrm{NaOH}$ ( $\mathrm{pH}$ 6-8), $\mathrm{NaHCO}_{3} / \mathrm{Na}_{2} \mathrm{CO}_{3}$ (pH 9-10) or $\mathrm{Na}_{2} \mathrm{HPO}_{4} / \mathrm{NaOH}(\mathrm{pH} 11$ ). Antibiotic susceptibility was examined as described by Groth et al. (2004), using antibiotic discs on ISP medium 2. The morphological, cultural, physiological and biochemical characteristics of strain SCSIO $01248^{\mathrm{T}}$ are given in Table 1, Fig. 1 and the species description.

Diaminopimelic acid and whole-cell sugars were analysed according to the procedures developed by Hasegawa et al. (1983). Menaquinones were isolated using the methods of Minnikin et al. (1984) and separated by HPLC (Kroppenstedt, 1982). Polar lipids were extracted and examined by using published procedures (Minnikin et al., 1979; Collins \& Jones, 1980). Fatty acids were analysed by using standard methods (Sasser, 1990) and version 6.0 of the Sherlock Microbial Identification System (MIDI). The genomic DNA G+C content was determined by HPLC (Mesbah et al., 1989).

The cell-wall peptidoglycan of strain SCSIO $01248^{\mathrm{T}}$ contains LL-diaminopimelic acid, glycine, asparagine, glutamic acid

\section{Table 1. Comparison of characteristics of strain SCSIO $01248^{\top}$ and S. radiopugnans DSM $41901^{\top}$}

All data were obtained in this study with the exception of the major fatty acid profile of $S$. radiopugnans $\mathrm{R} 97^{\mathrm{T}}\left(=\mathrm{DSM} 41901^{\mathrm{T}}\right)$, which was taken from Mao et al. (2007).

\begin{tabular}{|c|c|c|}
\hline Characteristic & SCSIO $01248^{\mathrm{T}}$ & S. radiopugnans DSM $41901^{\mathrm{T}}$ \\
\hline Spore chain morphology & Straight to spiral & Spiral \\
\hline Spore surface ornamentation & Smooth to rough & Rough to warty \\
\hline \multicolumn{3}{|l|}{ Utilization of: } \\
\hline Arabinose & - & + \\
\hline Cellobiose & + & - \\
\hline D-Mannitol & - & + \\
\hline L-Rhamnose & - & + \\
\hline D-Ribose & - & + \\
\hline Trehalose & + & - \\
\hline Xylitol & - & + \\
\hline Citrate & - & + \\
\hline Hydrolysis of Tween 20 & + & - \\
\hline Temperature range for growth $\left({ }^{\circ} \mathrm{C}\right)$ & $10-45$ & $20-50$ \\
\hline $\mathrm{NaCl}$ concentration for growth (\%) & $0-7.5$ & $0-7$ \\
\hline Growth at $\mathrm{pH} 5$ and 11 & - & + \\
\hline \multicolumn{3}{|l|}{ Major menaquinones $(\% \text { of total })^{*}$} \\
\hline MK-9 $\left(\mathrm{H}_{6}\right)$ & 36 & 65 \\
\hline MK- $9\left(\mathrm{H}_{8}\right)$ & 55 & 31 \\
\hline Major fatty acids ( $\%$ of total $) \dagger$ & $\begin{array}{c}\mathrm{i}-\mathrm{C}_{16: 0}(29.9), \text { ai- } \mathrm{C}_{15: 0}(14.9), \mathrm{i}-\mathrm{C}_{16: 1} \mathrm{H}(14.3), \\
\mathrm{i}-\mathrm{C}_{14: 0}(10.4), \text { ai- } \mathrm{C}_{17: 0}(7.8), \mathrm{i}-\mathrm{C}_{15: 0}(10.9) \\
\mathrm{C}_{16: 1} \text { cis9 (7.6), 9-methyl } \mathrm{C}_{16: 0}(4.2)\end{array}$ & $\begin{array}{l}\mathrm{i}-\mathrm{C}_{16: 0}(34.5), \text { ai- } \mathrm{C}_{15: 0}(15.4), \\
\mathrm{i}-\mathrm{C}_{16: 1} \mathrm{H}(14.2), \mathrm{i}-\mathrm{C}_{14: 0}(5.6), \\
\text { ai- }_{17: 0}(9.1), \text { ai- } \mathrm{C}_{17: 1} \operatorname{cis} 8(5.2)\end{array}$ \\
\hline Phospholipids $\ddagger$ & DPG, PE, PG, PI, PIM, PLs & DPG, PE, PG, PI, PLs \\
\hline DNA G $+\mathrm{C}$ content $(\mathrm{mol} \%)^{*}$ & 71.9 & 73.3 \\
\hline
\end{tabular}

${ }^{\star}$ Data for the two strains collected under the same culture conditions.

†ai, Anteiso-branched; i, iso-branched.

‡DPG, Diphosphatidylglycerol; PE, phosphatidylethanolamine; PG, phosphatidylglycerol; PI, phosphatidylinositol; PIM, phosphatidylinositol mannosides; PLs, unknown phospholipids. 


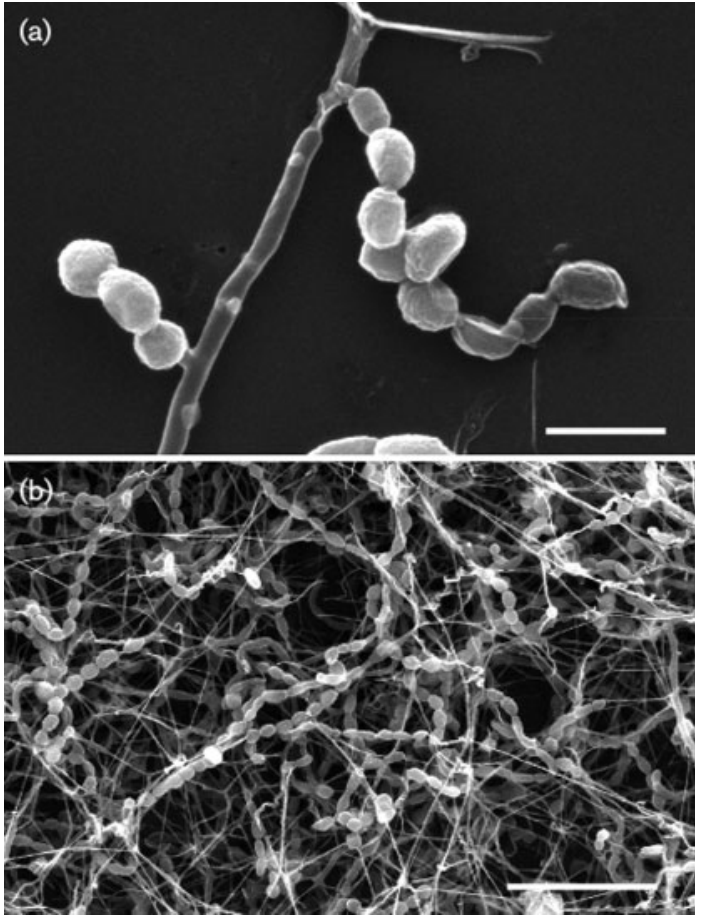

Fig. 1. Scanning electron micrographs of the spore chains (a) and aerial mycelium (b) of strain SCSIO $01248^{\top}$, as seen after incubation for 14 days on ISP medium 2 at $28{ }^{\circ} \mathrm{C}$. Bars, $2 \mu \mathrm{m}$ (a) and $10 \mu \mathrm{m}$ (b).

and alanine but no detectable sugar. The polar lipids were phosphatidylglycerol, diphosphatidylglycerol, phosphatidylethanolamine, phosphatidylinositol, phosphatidylinositol mannosides and three unknown phospholipids. The menaquinones were MK-9 $\left(\mathrm{H}_{8}\right)(55.5 \%)$, MK-9 $\left(\mathrm{H}_{6}\right)(36.8 \%)$, MK-9 $\left(\mathrm{H}_{10}\right)(3.8 \%)$, MK-9 $\left(\mathrm{H}_{4}\right)(1.6 \%)$, MK-10 $\left(\mathrm{H}_{8}\right)(1.5 \%)$ and MK-10 $\left(\mathrm{H}_{6}\right)(0.8 \%)$. The fatty acids consisted mainly of iso- $\mathrm{C}_{16: 0}(29.9 \%)$, anteiso- $\mathrm{C}_{15: 0}(14.9 \%)$, iso- $\mathrm{C}_{16: 1} \mathrm{H}$ $(14.3 \%)$, iso- $\mathrm{C}_{14: 0}(10.4 \%)$, iso- $\mathrm{C}_{15: 0}(10.9 \%)$, anteiso$\mathrm{C}_{17: 0}(7.8 \%), \mathrm{C}_{16: 1} \operatorname{cis} 9(7.6 \%)$ and 9-methyl $\mathrm{C}_{16: 0}(4.2 \%)$. The genomic DNA G $+C$ content was 71.9 mol\%.

Extraction of genomic DNA and PCR-mediated amplification and sequencing of the $16 \mathrm{~S}$ rRNA gene of strain SCSIO $01248^{\mathrm{T}}$ were carried out according to Li et al. (2007). Multiple alignments with sequences of the recognized Streptomyces species that appeared most closely related to the novel strain and evaluation of the levels of sequence similarity were carried out using CLUSTAL_X (Thompson et al., 1997). Phylogenetic analyses were performed using neighbour-joining (Saitou \& Nei, 1987), maximumlikelihood (Felsenstein, 1981) and maximum-parsimony (Fitch, 1971) methods. A phylogenetic tree was constructed using the neighbour-joining method of Saitou \& Nei (1987), $K_{\text {nuc }}$ values (Kimura, 1983) and the MEGA5 software package (Tamura et al., 2011). The topology of the phylogenetic tree was evaluated by the bootstrap resampling method of Felsenstein (1985), with 1000 replicates.
DNA-DNA hybridization experiments were performed between strain SCSIO $01248^{\mathrm{T}}$ and the type strain of the most closely related established species using the optical renaturation method (De Ley et al., 1970; Huß et al., 1983; Jahnke, 1992) and a UV1601 spectrophotometer (Shimadzu).

The results of BLAST analysis of 16S rRNA gene sequences indicated that strain SCSIO $01248^{\mathrm{T}}$ was most closely related to S. radiopugnans $\mathrm{R}^{\mathrm{T}}{ }^{\mathrm{T}}$ ( $98.8 \%$ sequence similarity; Mao et al., 2007) followed by S. macrosporus NBRC $14748^{\mathrm{T}}$ $(97.5 \%)$ and S. megasporus NBRC $14749^{\mathrm{T}}(97.3 \%)$. Several characteristics of strain SCSIO $01248^{\mathrm{T}}$, the production of long, spirally coiled chains of spores, the presence of LLdiaminopimelic acid in the cell-wall peptidoglycan, MK$9\left(\mathrm{H}_{8}\right)$ and MK-9 $\left(\mathrm{H}_{6}\right)$ as the predominant menaquinones and iso- $\mathrm{C}_{14: 0}$, iso- $\mathrm{C}_{16: 0}$, anteiso- $\mathrm{C}_{15: 0}$ and anteiso- $\mathrm{C}_{17: 0}$ as major fatty acids, were consistent with those of established Streptomyces species.

In a phylogenetic tree based on the $16 \mathrm{~S}$ rRNA gene sequences of strain $01248^{\mathrm{T}}$ and its closest known relatives, the novel strain formed a distinct subclade and clustered with $S$. radiopugnans $\mathrm{R}^{\mathrm{T}}{ }^{\mathrm{T}}$, close to $S$. macrosporus NBRC $14748^{\mathrm{T}}$, S. megasporus NBRC $14749^{\mathrm{T}}$, S. glaucosporus NBRC $15416^{\mathrm{T}}$ and $S$. thermolineatus NBRC $14750^{\mathrm{T}}$ (Fig. 2 ). The topologies of phylogenetic trees built using the maximum-likelihood and maximum-parsimony algorithms were similar to those of the tree constructed using neighbour-joining analysis (Fig. 2).

Several years ago, Stackebrandt \& Ebers (2006) recommended an increase of about $2 \%$ (from $97 \%$ to $98.7-$ $99 \%$ ) in the threshold for 16S rRNA gene sequence similarity used to determine the uniqueness of a novel isolate, provided that this level of difference in the sequences was supported by clear phenotypic differences. In this study, therefore, DNA-DNA relatedness experiments were only carried out between strain SCSIO $01248^{\mathrm{T}}$ and the type strain of established species to which it appeared most closely related: $S$. radiopugnans DSM $41901^{\mathrm{T}}$. The mean level of DNA-DNA relatedness recorded between these two strains (over three replicate experiments) was $40 \%$ and therefore well below the $70 \%$ cut-off point recommended for the delineation of genomic species (Stackebrandt \& Goebel, 1994). In addition, strain SCSIO $01248^{\mathrm{T}}$ can be readily differentiated from $S$. radiopugnans DSM $41901^{\mathrm{T}}$ on the basis of $\mathrm{pH}$ and temperature ranges for growth, sole carbon sources for growth, cellular phospholipids and predominant menaquinones and fatty acids (Table 1). Based on phylogenetic and phenotypic evidence, strain SCSIO $01248^{\mathrm{T}}$ represents a novel species within the genus Streptomyces, for which the name Streptomyces nanhaiensis sp. nov. is proposed.

\section{Description of Streptomyces nanhaiensis sp. nov.}

Streptomyces nanhaiensis [nan.hai.en'sis. N.L. masc. adj. nanhaiensis of or pertaining to Nanhai (South China Sea), where the type strain was isolated]. 


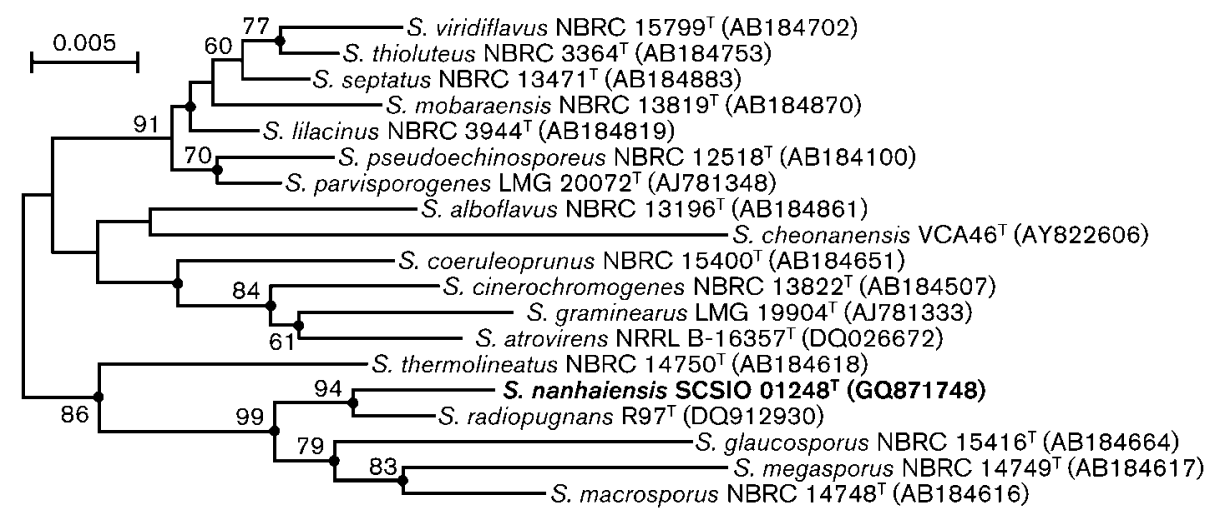

Fig. 2. Neighbour-joining phylogenetic tree based on nearly complete $16 \mathrm{~S}$ rRNA gene sequences, showing the relationships between strain SCSIO $01248^{\top}$ and its closely related neighbours within the genus Streptomyces. Filled circles indicate nodes that were also obtained in both maximum-parsimony and maximum-likelihood trees. Bootstrap values (expressed as percentages of 1000 replications) $>50 \%$ are given at branching points. Bar, 0.005 substitutions per nucleotide position.

Gram-reaction-positive, aerobic actinomycete that forms yellow-white substrate mycelium and grey-white aerial hyphae. The hyphae differentiate into straight to spiral chains of spores, each chain comprising about 10 spores. The spores are $1-2 \mu \mathrm{m}$ in diameter, with a smooth to rough surface. Grows well on ISP 2, ISP 3, ISP 4 and ISP 5 media, Czapek's solution agar and nutrient agar at $28{ }^{\circ} \mathrm{C}$, but aerial mycelium is not easily observed on potato agar. Soluble pigments are not produced. Acetate, cellobiose, fructose, fucose, D-galactose, D-glucose, maltose, sucrose and D-xylose can be used as sole carbon sources for growth, but not arabinose, citrate, dulcitol, inositol, lactose, D-mannitol, Dmannose, L-rhamnose, D-ribose, D-sorbitol, xylitol or raffinose. Positive for hydrolysis of starch and Tweens 20, 40 and 60 , nitrate reduction and catalase and weakly positive for hydrolysis of cellulose but negative for hydrolysis of gelatin and Tween 80 , milk coagulation and peptonization, $\mathrm{H}_{2} \mathrm{~S}$ and melanin production, utilization of urea and oxidase activity. Temperature, $\mathrm{pH}$ and $\mathrm{NaCl}$ concentration ranges for growth are $10-45{ }^{\circ} \mathrm{C}, \mathrm{pH} 6-10$ and $0-7.5 \%(\mathrm{w} / \mathrm{v})$; the corresponding optima are $28-37{ }^{\circ} \mathrm{C}$, $\mathrm{pH} 7-8$ and $3 \%(\mathrm{w} / \mathrm{v})$ $\mathrm{NaCl}$. Susceptible to ( $\mu \mathrm{g}$ per disc) penicillin G (10), erythromycin (15), gentamicin (10), streptomycin (10), tetracycline (30), vancomycin (30), novobiocin (30), lincomycin (2), rifampicin (5), netilmicin (30), amoxicillin (10), ciprofloxacin (5), amikacin (30), tobramycin (10), neomycin (10) and chloramphenicol (30) but resistant to sulfamethoxazole (23.75), ampicillin (10) and norfloxacin (10). The cell wall contains LL-diaminopimelic acid, glycine, asparagine, glutamate and alanine. The polar lipids are phosphatidylglycerol, diphosphatidylglycerol, phosphatidylethanolamine, phosphatidylinositol, phosphatidylinositol mannosides and three unknown phospholipids. The predominant menaquinones are MK-9 $\left(\mathrm{H}_{8}\right)$ and MK-9 $\left(\mathrm{H}_{6}\right)$. The major fatty acids are iso- $\mathrm{C}_{16: 0}$, anteiso- $\mathrm{C}_{15: 0}$ and iso- $\mathrm{C}_{16: 1} \mathrm{H}$.

The type strain, SCSIO $01248^{\mathrm{T}}\left(=\mathrm{DSM} 41926^{\mathrm{T}}=\mathrm{KCTC}\right.$ $19401^{\mathrm{T}}=$ CCTCC AA $208007^{\mathrm{T}}$ ), was isolated from a sediment sample collected at a depth of $1632 \mathrm{~m}$ from the northern South China Sea. Its genomic DNA G + C content is $71.9 \mathrm{~mol} \%$.

\section{Acknowledgements}

The authors are grateful to Professor Hans-Peter Klenk, who kindly provided S. radiopugnans DSM $41901^{\mathrm{T}}$. This research was supported by the National Basic Research Program of China (grant 2010CB833801), the National Natural Science Foundation of China (grant 40906075) and the Knowledge Innovation Program of the Chinese Academy of Sciences (grants KSCX2-YW-G-065, KSCX2EW-G-12 and KZCX2-YW-JC202).

\section{References}

Collins, M. D. \& Jones, D. (1980). Lipids in the classification and identification of coryneform bacteria containing peptidoglycans based on 2,4-diaminobutyric acid. J Appl Bacteriol 48, 459-470.

De Ley, J., Cattoir, H. \& Reynaerts, A. (1970). The quantitative measurement of DNA hybridization from renaturation rates. Eur $J$ Biochem 12, 133-142.

Felsenstein, J. (1981). Evolutionary trees from DNA sequences: a maximum likelihood approach. J Mol Evol 17, 368-376.

Felsenstein, J. (1985). Conference limits on phylogenies: an approach using the bootstrap. Evolution 39, 783-791.

Fitch, W. M. (1971). Towards defining the course of evolution: minimum change for a specific tree topology. Syst Zool 20, 406-416.

Groth, I., Rodríguez, C., Schütze, B., Schmitz, P., Leistner, E. \& Goodfellow, M. (2004). Five novel Kitasatospora species from soil: Kitasatospora arboriphila sp. nov., $K$. gansuensis sp. nov., $K$. nipponensis sp. nov., $K$. paranensis sp. nov. and $K$. terrestris sp. nov. Int J Syst Evol Microbiol 54, 2121-2129.

Hasegawa, T., Takizaea, M. \& Tanida, S. (1983). A rapid analysis for chemical grouping aerobic actinomycetes. J Gen Appl Microbiol 29, 319-322.

Hayakawa, M. \& Nomura, S. (1987). Humic acid-vitamin agar. A new medium for the selective isolation of soil actinomycetes. J Ferment Technol 65, 501-509. 
Huß, V. A. R., Festl, H. \& Schleifer, K. H. (1983). Studies on the spectrophotometric determination of DNA hybridization from renaturation rates. Syst Appl Microbiol 4, 184-192.

Jahnke, K. D. (1992). BASIC computer program for evaluation of spectroscopic DNA renaturation data from Gilford System 2600 spectrophotometer on a PC/XT/AT type personal computer. J Microbiol Methods 15, 61-73.

Kämpfer, P. (2006). The family Streptomycetaceae. Part I: Taxonomy. In The Prokaryotes: a Handbook on the Biology of Bacteria, 3rd edn, vol. 3, p. 538-604. Edited by M. Dworkin, S. Falkow, E. Rosenberg, K. H. Schleifer \& E. Stackebrandt. New York: Springer.

Kelly, K. L. (1964). Inter-Society Color Council - National Bureau of Standards Color Name Charts Illustrated with Centroid Colors. Washington, DC: US Government Printing Office.

Kieser, T., Bibb, M. J., Buttner, M. J., Chater, K. F. \& Hopwood, D. A. (2000). Practical Streptomyces Genetics, 2nd edn. Norwich: The John Innes Foundation.

Kimura, M. (1983). The Neutral Theory of Molecular Evolution. Cambridge: Cambridge University Press.

Kroppenstedt, R. M. (1982). Separation of bacterial menaquinones by HPLC using reverse phase (RP18) and a silver loaded ion exchanger as stationary phases. J Liq Chromatogr 5, 2359-2367.

Li, W. J., Xu, P., Schumann, P., Zhang, Y. Q., Pukall, R., Xu, L. H., Stackebrandt, E. \& Jiang, C. L. (2007). Georgenia ruanii sp. nov., a novel actinobacterium isolated from forest soil in Yunnan (China), and emended description of the genus Georgenia. Int J Syst Evol Microbiol 57, 1424-1428.

Mao, J., Tang, Q. Y., Zhang, Z. D., Wang, W., Wei, D., Huang, Y., Liu, Z. H., Shi, Y. H. \& Goodfellow, M. (2007). Streptomyces radiopugnans sp. nov., a radiation-resistant actinomycete isolated from radiationpolluted soil in China. Int J Syst Evol Microbiol 57, 2578-2582.

Mesbah, M., Premachandran, U. \& Whitman, W. B. (1989). Precise measurement of the $\mathrm{G}+\mathrm{C}$ content of deoxyribonucleic acid by highperformance liquid chromatography. Int J Syst Bacteriol 39, 159-167.

Minnikin, D. E., Collins, M. D. \& Goodfellow, M. (1979). Fatty acid and polar lipid composition in the classification of Cellulomonas, Oerskovia and related taxa. J Appl Bacteriol 47, 87-95.

Minnikin, D. E., O'Donnell, A. G., Goodfellow, M., Alderson, G., Athalye, M., Schaal, A. \& Parlett, J. H. (1984). An integrated procedure for the extraction of bacterial isoprenoid quinones and polar lipids. Microbiol Methods 2, 233-241.

Saitou, N. \& Nei, M. (1987). The neighbor-joining method: a new method for reconstructing phylogenetic trees. Mol Biol Evol 4, 406-425.

Sasser, M. (1990). Identification of bacteria by gas chromatography of cellular fatty acids. USFCC Newsl 20, 16.
Schrempf, H. (2006). The Family Streptomycetaceae. Part II: Molecular biology. In The Prokaryotes: a Handbook on the Biology of Bacteria, 3rd edn, vol. 3, pp. 605-622. Edited by M. Dworkin, S. Falkow, E. Rosenberg, K. H. Schleifer \& E. Stackebrandt. New York: Springer.

Shirling, E. B. \& Gottlieb, D. (1966). Methods for characterization of Streptomyces species. Int J Syst Bacteriol 16, 313-340.

Smibert, R. M. \& Krieg, N. R. (1994). Phenotypic characterization. In Methods for General and Molecular Bacteriology, pp. 607-654. Edited by P. Gerhardt, R. G. E. Murray, W. A. Wood \& N. R. Krieg. Washington, DC: American Society for Microbiology.

Stackebrandt, E. \& Ebers, J. (2006). Taxonomic parameters revisited: tarnished gold standards. Microbiol Today 33, 152-155.

Stackebrandt, E. \& Goebel, B. M. (1994). Taxonomic note: a place for DNA-DNA reassociation and $16 \mathrm{~S}$ rRNA sequence analysis in the present species definition in bacteriology. Int J Syst Bacteriol 44, 846849.

Tamura, K., Peterson, D., Peterson, N., Stecher, G., Nei, M. \& Kumar, S. (2011). MEGA5: molecular evolutionary genetics analysis using maximum likelihood, evolutionary distance, and maximum parsimony methods. Mol Biol Evol 28, 2731-2739.

Thompson, J. D., Gibson, T. J., Plewniak, F., Jeanmougin, F. \& Higgins, D. G. (1997). The CLUSTAL_X windows interface: flexible strategies for multiple sequence alignment aided by quality analysis tools. Nucleic Acids Res 25, 4876-4882.

Tian, X.-P., Zhi, X.-Y., Qiu, Y.-O., Zhang, Y.-Q., Tang, S.-K., Xu, L.-H., Zhang, S. \& Li, W.-J. (2009). Sciscionella marina gen. nov., sp. nov., a marine actinomycete isolated from a sediment in the northern South China Sea. Int J Syst Evol Microbiol 59, 222-228.

Tindall, B. J., Sikorski, J., Smibert, R. A. \& Krieg, N. R. (2007). Phenotypic characterization and the principles of comparative systematics. In Methods for General and Molecular Microbiology, pp. 330-393. Edited by C. A. Reddy, T. J. Beveridge, J. A. Breznak, G. A. Marzluf, T. M. Schmidt \& L. R. Snyder. Washington, DC: American Society for Microbiology.

Waksman, S. A. (1961). The Actinomycetes. Classification, Identification and Descriptions of Genera and Species. Baltimore: Williams \& Wilkins.

Williams, S. T., Sharp, M. E. \& Holt, J. G. (editors) (1989). Bergey's Manual of Systematic Bacteriology, vol. 4. Baltimore: Williams \& Wilkins.

Xu, P., Li, W. J., Tang, S. K., Zhang, Y. Q., Chen, G. Z., Chen, H. H., Xu, L. H. \& Jiang, C. L. (2005). Naxibacter alkalitolerans gen. nov., sp. nov., a novel member of the family 'Oxalobacteraceae' isolated from China. Int J Syst Evol Microbiol 55, 1149-1153. 